\title{
Seasonal variation of the productivity and quality of permanent pastures in Adisols of temperate regions
}

\author{
R. Demanet ${ }^{1 *}$, M. L. Mora ${ }^{2}$, M. Á. Herrera ${ }^{3}$ H. Miranda ${ }^{1}$ and J. M. Barea ${ }^{4}$ \\ ${ }^{1}$ Facultad de Ciencias Agropecuarias y Forestales. Universidad de La Frontera, Temuco, Chile. *Corresponding \\ autor: rolando.demanet@ufrontera.cl 22 Center of Plant, Soil Interaction and Natural Resources Biotechnology, \\ Scientific and Technological Bioresource Nucleus, Universidad de La Frontera, Temuco, Chile. ${ }^{3}$ Facultad de \\ Agronomía Universidad de Córdoba, España ${ }^{4}$ Departamento de Microbiología del Suelo y Sistemas Simbióticos, \\ Estación Experimental del Zaidin, CSIC, Profesor Albareda 1, 18008 Granada, Spain
}

\begin{abstract}
With the aim of evaluating the productivity (dry matter yield) and quality (protein and fiber) of pastures in temperate regions of Chile a long-term monitoring experiment was carried out in a representative farm in these regions. The study was carried during the years 2002 - 2012 in a farm located at Region of Los Ríos, Chile. The study area was split into fifteen pasture sites, which were evaluated dry matter production by means of the standardized methodology, which considers the location on each pasture site a grazing exclusion cage. With the information generated during the 11 years of measurements, a trend pattern interpolation was developed by a polynomial regression model using fifth grade and centering the independent variable from the second grade on. Each result was classified according to the ranking provided by the BLUP methodology, comparing the results obtained with the average. The analysis of variance mixed model, determined by the variance components, indicated that $60 \%$ of the total variation in dry matter production is attributed to seasonality. Only $2.6 \%$ of the variation was attributable to the year while a $0.9 \%$ was due to differences between pastures sites, during the eleven years of study, with no significant data $(p>0.05)$. The seasonal distribution of production, concentrated its performance in spring and highest performing months were November, December, January. The quality measured as protein and fiber content of the pasture, does not present statistical differences between years and only differences were determined by seasonality.
\end{abstract}

Keywords: Dry matter production, pasture quality and productivity, grazing systems, growth models

\section{Introduction}

Permanent pastures are the main source of food for cattle in temperate regions of the World, being the lowest-cost food for grazing animals (Pembletona et al., 2012).
In Chile, the permanent pastures of the temperate regions are situated in a wide area located in between the parallels $35^{\circ}$ and $42^{\circ}$. These pastures are developed in soils with a volcanic origin, including 
Andisols and Ultisols. Such a temperate climate included a characteristic winter rainfall.

Productivity of a permanent pasture area, having a homogeneous soil and climate, is usually expressed by means of growth models. The produced curves can provide basic information for modeling the use of forage in grazing systems (Delagarde and O'Donovan, 2005). Seasonal variations determined by the weather, plant nutrition and management, define the availability and quality of forage throughout the year. These curves are in fact the primary tool to build predictive models of performance and handling of feed resources in livestock production systems (Fy, et al., 2011).

In the temperate zone of Chile different curve models have been developed to represent the growth of pastures in different sites and with different levels of intervention and management (Teuber, 2009). However, all of these curves shown results achieved in a short time period and fail to represent a yearly effect.

All predictive models require long-term field information, and at many points within the study area. Obviously, the level of complexity of a particular model curve depends on the amount and quality of information available for building the model (Corson et al., 2007). The complexity or simplicity of a model curve of plant growth is a subjective concept. Complex models incorporate several variables, such as photosynthetic efficiency and mesophyll conductance and leaf water potential effects on metabolic processes (Vico and Porporato, 2008). Simple models predict and estimate growth through indirect field measurements with instruments of easy access and use: rising plate meter, sward height measuring ultrasonic distance sensor with An - radiometric and spectral reflections and visually (Fricke and Wachendorf, 2013).
In addition to changes in the productivity, basically dry matter production, pastures in temperate areas exhibit also changes in the quality o of the produced forage, changes which are related to the growth stage, nutrition, frequency and intensity of pasture use throughout the year, and season (Beecher et al., 2013). Elaborating quality forage production curves, which represent protein, fiber, and energy in the forage, is critical to define the nutritional value of pastures and build balanced diets for grazing animals (Owens et al., 2008). In temperate zones, production and protein ratio in pastures have a seasonal change, whose size and trends is needed to know to develop efficient and productive farming systems (Wang and Schjoerring, 2012).

The protein content of the pasture is dependent on genetic and environmental conditions while the absorption efficiency of nitrogen available from the soil depends on the plant species and their genetic characteristics. Protein production is related to soil organic matter content (Cartes et al., 2009), level of humidity, temperature and supply generated by the applied organic and inorganic fertilization during the production period (Cameron et al., 2013). Various strategies have been followed to increase both the efficient use of the available nitrogen in the soil and the true protein content in pastures (Giller et al., 2004). Among these strategies it has been investigated a reduced use of synthetic nitrogen fertilizers, splitting their annual application rate, use of slow release fertilizer (Adams et al., 2013), adjustment of supply the current demand, use of urease and/or nitrification inhibitors (Zaman et al., 2009), application of organic fertilizers, increased intervals between defoliation (Kennedy et al., 2006), and use of plants can take up and use nitrogen captured from soil. All these practices comply with the objective of increasing the efficiency of nitrogen use, reduce air pollution and 
increase the protein content of the plants (Andrews et al., 2007).

It can be also considered that pasture use efficiency of nitrogen available in the soil is reduced as much of this nitrogen is lost in the soil - plant, through processes of ammonia volatilization, nitrification, denitrification or leaching, and by erosion and surface runoff (Agouridis et al., 2005).

Another component of interest is the content of fiber, either the Neutral Detergent Fiber (NDF) or Acid Detergent Fiber (ADF) fractions, in the forage. These parameters are inversely related to forage digestibility and define the consumption capacity of grazing animals. The fiber content is depending on the growth stage, the proportion of plant components, species and cultivar (Beecher et al., 2013). The tetraploid plants have a proportionally lower fiber content and higher digestibility, because of their larger epidermal and mesophyll cells and their higher ratio of cell wall to cell contents (Stewart and Hayes, 2011).

Information on pasture production and quality is therefore a useful tool in predicting and preparing balanced diets, which are the basis for making timely and effective decisions, and that achieve optimum use of forage resources in a system pastoral (Stewart et al., 2014)

With the aim of evaluating the productivity (dry matter yield) and quality of pastures in temperate regions of Chile a long-term monitoring experiment was carried out in a representative farm in these regions. This was in fact the main objective of this research, but ascertaining the factors affecting pasture productivity and quality was also a part of the targets. Accordingly, two alternative hypotheses were formulated: (a) the productivity and quality of permanent pastures in volcanic soils (Andisols) in the temperate regions of Chile is determined by the single effect of the year, seasonality or the pasture location, or (b) by the combined effect of these variables.

\section{Materials and Methods}

The study was carried during the years 2002-2012 in a farm called "Cerro Azul", located at the Lake Ranco basin, Region of Los Ríos, Chile, situated in between the parallels $39^{\circ} 58^{\prime}$ and $40^{\circ} 36^{\prime} \mathrm{LS}$, and the meridians $72^{\circ} 39^{\prime} y 71^{\circ} 42^{\prime} \mathrm{LO}$. This farm has 4,500 ha, where silvo-agropastoral activities are being developed.

\subsection{Characteristics of the Study Area}

The landscape of the test basin characteristically has a high proportion of the native forest, which represents a $51 \%$ of its surface area. The most representative trees, all of them evergreen, are Nothofagus obliqua (Mirb.) Oerst., Nothofagus alpina (P. et E.) Oerst., Nothofagus dombeyi (Mirb.) Oerst. y Nothofagus dombeyi (Mirb.) Oerst., Nothofagus alpina (P. et E.) Oerst., Laureliopsis philippiana (Looser).

The study area has a glacial origin and is predominantly hill-shaped where the sloped planes are exposed to hydraulic erosion processes.

The target soil is an Andisol, serie Piedras Negras, originated by volcanic ashes depositions on lacustrian planes situated in the pre-Andean range. Is a deep soil and its texture is silty loam in surface, having a black color, while is clay loam and brownish in depth. The substrate consists in cemented glacial-fluvial sediments.

The climate is characteristically temperate and rainy (Cfsb, after Köeppen) which the rains concentrated in winter. The average temperature is maintained less than $12^{\circ} \mathrm{C}$ with an annual rainfall of $2.200 \mathrm{~mm}$.

In the period 2002 - 2012, the study area provided an average annual rainfall of 2,066 $\mathrm{mm}$, with 231 days of occurrence of rainfall, concentrated in the period from March to September (Table 1). 
Table 1. Climatic variables in the study area $(2002-2012)$

\begin{tabular}{|c|c|c|c|c|c|c|c|c|c|c|c|c|c|}
\hline Parameter & $\mathrm{J}$ & $\mathrm{F}$ & M & A & M & $\mathrm{J}$ & $\mathrm{J}$ & A & $\mathrm{S}$ & $\mathrm{O}$ & $\mathrm{N}$ & $\mathrm{D}$ & Annual \\
\hline Rainfall (mm). & 92.8 & 45.7 & 89 & 167 & 215.6 & 293.5 & 253.1 & 332.4 & 300 & 98.5 & 131.8 & 47.3 & 2066.7 \\
\hline Cumulative rainfall (mm) & 92.8 & 138.5 & 227.5 & 394.5 & 610.1 & 903.6 & 1156.7 & 1489.1 & 1789.1 & 1887.6 & 2019.4 & 2066.7 & \\
\hline Number days with rain & 13 & 12 & 22 & 26 & 26 & 22 & 21 & 26 & 23 & 17 & 15 & 8 & 231 \\
\hline Average temperatura $\left({ }^{\circ} \mathrm{C}\right)$ & 14.2 & 14.8 & 12.1 & 9.4 & 7.8 & 6.4 & 5.6 & 5.7 & 7.8 & 8.6 & 11.1 & 13.6 & \\
\hline Minimum temperature ${ }^{\circ} \mathrm{C}$ & 4.9 & 4.6 & 2.5 & 1.4 & -1.8 & -2.4 & -1.4 & -0.6 & 0.3 & 1.3 & 2.8 & 2.4 & \\
\hline Maximum temperature ${ }^{\circ} \mathrm{C}$ & 28.5 & 31.6 & 25.1 & 23.3 & 16.4 & 16.7 & 14.5 & 15.9 & 17.4 & 24.1 & 23.4 & 25.8 & \\
\hline
\end{tabular}

\subsection{Pasture management}

The study area was split into fifteen pasture sites, which were evaluated for eleven years (2002-2011). Annually, all pastures were fertilized with $60 \mathrm{~kg} \mathrm{P} /$ ha, $30 \mathrm{~kg} \mathrm{~N} / \mathrm{ha}, 22 \mathrm{~kg} \mathrm{2O}, \mathrm{MgO} 18 \mathrm{~kg}, 22 \mathrm{~kg} \mathrm{~S} /$ ha. In years 1, 4 and 8, was also applied in March1 Ton/ha of dolomite. During the study period the pastures were grazed by beef cattle and subjected to a system of rotational grazing management, with an annual average stocking rate of 2.2 animal units per hectare. The average botanical composition of pastures was $78 \%$ of perennial grasses, legumes $3 \%$ and $19 \%$ of naturalized architecture of different species and growth habit.

\subsection{Nutrient Content in Soil}

The soil analysis was performed according to the methodology proposed by Sadzawka et al. (2006) and updated by the National Accrediting
Commission of the Chilean Society of Soil Science.

The $\mathrm{pH}$ was determined in a suspension of ground calcium chloride $(0.01 \mathrm{M})$, in a ratio soil: solution 1:2.5 OM content was determined by wet combustion with a mixture of sodium dichromate $(0.5 \mathrm{M})$ and sulfuric acid (96\%) acid was measured by colorimetry after chromate reduction.

Phosphorus was measured by the technique of Olsen based on an extraction with a solution of $0.5 \mathrm{M}$ sodium bicarbonate at $\mathrm{pH}$ 8.5.The bases of the soil were estimated from the removal of the exchangeable cations $(\mathrm{Ca}, \mathrm{Mg}, \mathrm{Na}, \mathrm{K})$ with ammonium acetate (1 $\mathrm{M})$ at $\mathrm{pH}$ 7.0. The available sulfur was measured by extraction with $\mathrm{Ca}\left(\mathrm{H}_{2} \mathrm{PO}_{4}\right) 0.01 \mathrm{~mol} / \mathrm{L}$. Cation exchange capacity was determined from the amount of $\mathrm{Ca}+\mathrm{Mg}+\mathrm{Na}+\mathrm{K}+\mathrm{Al}$ interchangeable. The results showed that pastures evaluated in this study were developed in a representative Andisol temperate with high organic matter, acid $\mathrm{pH}$, phosphorus intermediate and $2.43 \%$ aluminum saturation (Table 2 ). 
Table 2. $\mathrm{pH}$ and nutrient concentration in the target soil

\begin{tabular}{lccc}
\hline Parameters & Average & Maximum & Minimum \\
\hline $\mathrm{pH} \mathrm{H} \mathrm{O}_{2} \mathrm{O}$ & 5.73 & 5.79 & 5.69 \\
\hline Organic matter $(\%)$ & 24.8 & 25.6 & 24,00 \\
\hline Olsen P $\left(\mathrm{mg} \mathrm{kg}^{-1}\right)$ & 15.75 & 17.68 & 14,00 \\
\hline $\mathrm{S}\left(\mathrm{mg} \mathrm{kg}^{-1}\right)$ & 8.86 & 13.48 & 4.08 \\
\hline $\mathrm{K}\left(\mathrm{cmolc} \mathrm{kg}^{-1}\right)$ & 0.51 & 0.62 & 0.4 \\
\hline $\mathrm{Na}\left(\mathrm{cmolc} \mathrm{kg}^{-1}\right)$ & 0.12 & 0.4 & 0.06 \\
\hline $\mathrm{Ca}\left(\mathrm{cmolc} \mathrm{kg}^{-1}\right)$ & 8.79 & 9.16 & 8.05 \\
\hline $\mathrm{Mg}\left(\mathrm{cmolc} \mathrm{kg}^{-1}\right)$ & 3.13 & 3.28 & 3.02 \\
\hline $\mathrm{Al}\left(\mathrm{cmolc} \mathrm{kg}^{-1}\right)$ & 0.2 & 0.23 & 0.17 \\
\hline $\mathrm{CEC}\left(\mathrm{cmolc} \mathrm{kg}^{-1}\right)$ & 12.83 & 13.31 & 12.2 \\
\hline $\mathrm{Al} \mathrm{saturation} \mathrm{\%}$ & 2.43 & 2.93 & 1.93 \\
\hline $\mathrm{Al} \mathrm{Ext.}\left(\mathrm{mg} \mathrm{kg}^{-1}\right)$ & 1406 & 1637 & 1190 \\
\hline $\mathrm{B}\left(\mathrm{mg} \mathrm{kg}^{-1}\right)$ & 0.44 & 0.48 & 0.38 \\
\hline $\mathrm{Zn}\left(\mathrm{mg} \mathrm{kg}^{-1}\right)$ & 4.18 & 4.65 & 3.47 \\
\hline
\end{tabular}

\subsection{Evaluations}

Evaluation of dry matter production was conducted by means of the methodology described by Soto and Teuber (1982), which considers the location on each pasture site a grazing exclusion cage $\left(0.85 \mathrm{~m}^{2}\right)$, which were rotated in each pasture site at each forage sampling, that was done every 30 days. Monthly shoot biomass growing inside the exclusion grazing cages was cut with scissors, as already did on a similar surface outside the exclusion cage. The difference between the production of forage growing inside the cage and that growing outside during the previous month, corresponds to the monthly growth of each pasture site. The grazing exclusion cages are moved around every month, in order to maintain the system of nutrient recycling performed by grazing animals.

The green forage produced inside and outside the grazing exclusion cages was weighed in the field with a 0.005 precision balance, where a sub- sample for the evaluation of dry matter content, proportion of species extracted and their nutrient content, was carried out in the Laboratory of meadows and pastures and Chemical Analysis of Soils and Plants, University of La Frontera, Temuco. Multiplying the green matter production value by the dry matter content, divided by 100 , gives the final parameter of "production of dry matter per hectare per month". Obviously, each year had a total of 12 pasture evaluations. The sum of the yield of each evaluation, gave rise to the annual yield. The daily growth rate was obtained from the division of the monthly production by the number of days in each month. The dry matter content in the sub-sample of green material from the inside of the grazing exclusion cages was determined by a standard procedure, as follows. The samples were homogenized in the laboratory and weighed on 0.005 precision balance and introduced in a previously paper to be subjected to drying in a forced air oven at $65^{\circ} \mathrm{C}$ for a maximum of 48 hours until constant weight. The dry matter content was expressed as a percentage value. 
The botanical composition was determined in forage sub-samples taken from the exclusion cages. The constituent species of each sample were separated manually into grasses, legumes and other. The proportion of species was expressed as a percentage.

The quality parameters of the pastures were evaluated from leaf samples taken from inside the grazing exclusion cages. The sub-samples were subjected to a drying process at $100^{\circ} \mathrm{C}$ in vacuum oven $(1.3 \times 104 \mathrm{~Pa})$ for 5 hours.

The leaf nitrogen content was determined using the Kjeldahl method. The conversion factor used from nitrogen to protein was 6.25 , as it is assumed that in temperate pasture nitrogen level of proteins is $16 \%$.

Fiber Content: The acid detergent fiber (ADF) and neutral detergent fiber (NDF) were determined through the method Van Soest (1994), which through the acid detergent extraction isolates cellulose cutting lignin insoluble minerals and other components, by solubilization of the hemicellulose and cell wall proteins. The neutral detergent fiber (NDF) has been obtained from the methodology developed by Van Soest (1994) and Goering and Van Soest (1994), a method by extracting with a neutral detergent insoluble or determines the total fiber.

\section{5. Statistical analyses}

With the information generated during the 11 years of measurements, a trend pattern interpolation was developed by a polynomial regression model using fifth grade and centering the independent variable from the second grade on. From the prediction residuals regression, outlier identification values were discarded through multivariate Mahalanobis distance (Varmuza and Filzmoser, 2009).

In order to identify the factors most influential on dry matter yield and quality, data were subjected to a mixed model in order to estimate the variance components of the random effects of year, month, pasture site and their interactions on pastures by REML (Restricted Maximum Likelihood). Finally the method BLUP (best linear predictor unbiased) was applied to predict and rank the levels of random factors in the order of high, medium and low and statistical significances were estimated relative to the overall average of each variable under study.

\section{Results and Discussion}

\subsection{Pasture growth}

The mathematical expression of the growth of temperate pastures is represented in this study by means of polynomial fitted curves. These curves try to predict the growth rate and performance of pastures in the target region at a given period. The results of this study indicated that the growth of temperate pasture fits a quintic polynomial with all coefficients resulting statistically significant $(p \leq 0.0001)$. The analysis of variance of the mixed model, determined by the variance of components, indicated that $60 \%$ of the total variation in dry matter production can be attributed to seasonality. Only $2.6 \%$ of the variation was attributable to the year and $0.9 \%$ to differences between pastures sites during the eleven years of study, which showed no significant values ( $p>$ 0.05 ). The only statistically significant interaction was month per year, with $10.35 \%$ of explained variance. In assessing daily growth rates, the months were clustered according to the ranking BLUP which showed that there are three categories during the year. The highest rate of growth was generated in the months of November, December and January with an average of $72 \mathrm{Kg} \mathrm{DM} /$ ha/day, which corresponds to spring and summer. At the intermediate level, the average was $37 \mathrm{Kg} \mathrm{DM} / \mathrm{ha} /$ day and corresponded to autumn and early spring, i.e., February, March, April, September and October. The lower rate of daily growth (10 Kg DM/ha/day), was recorded in late fall and winter, i. e., May, June, July and August (Table 3). 
Table 3. Month clustering of pasture growth according to BLUP ranking

\begin{tabular}{lcccc}
\hline Months & \multicolumn{3}{c}{ Kg DM/ha/day } & Significance BLUP \\
\hline & average & Máximum & minimum & \\
\hline November, December, January & 72 & 79 & 66 & $\mathrm{P} \leq 0.05$ \\
\hline February, March, April, September, October & 37 & 59 & 14 & $\mathrm{P}>0.05$ \\
\hline May, June, July, August & 10 & 18 & 5 & $\mathrm{P} \leq 0.05$ \\
\hline
\end{tabular}

The same trend was found when data were subjected to the polynomial fitting test as recorded in Figure 1 in form of curves predicting the mean tendency of the production rate over time. Actually, Figure 1 summarizes the dry matter yield of permanent pasture expressed either by month (A) or by day (B). Obviously, environmental conditions in spring and early summer (see also Table 2) enhance pasture productivity.

In developing a balanced diet of pastoral systems is necessary to know the size and growth trends and forage quality throughout the year. The polynomial fit of the data collected in eleven years at 15 sites pastures allowed to generate a predictive model of growth, where the incident is the seasonality factor and not the location of the pasture production and botanical composition. A similar trend, as the model shown in Figure 1, was obtained in other evaluation done in Chile and in another temperate region (Teuber, 2009). However, the scale of the changes is different, because of the high level of achievements by the productive pastures in the study site.

With the mathematical expression of forage production it is possible to predict the growth of pastures in the different periods of the year, and thereby develop feed balances, adjusting diets to regulate demand and supply processes conservation program surpluses. The optimization of the production processes of pasture and grazing management requires available results over time, which can be used in a permanent form in livestock systems to order the animal movement and define areas of use in different seasons. The seasonal pastures, shows the difficulty possessing pastoral livestock systems, in adjusting stocking addition to the continuing need to adjust diets due to the heterogeneity of grass growth.

With the polynomial model it was possible to quantify the trend of monthly average, daily growth and dry matter from pasture, over time, with a level of significance $(p \leq 0.0001)$. The variations in the seasonal growth of pasture use determine the frequency of grazing (Holmes et al., 2002). Under optimal conditions of use, rotation lengths vary between 15 and 35 days in spring and 25 and 90 days, in autumn and winter (Holmes et al., 2002). The results indicate that periods without grazing pastures can be maintained only if availability to the sustainability of the system is adjusted.

Measuring the growth of pastures in grazing systems is a complex issue that relates the climate variations between seasons and the interaction soil - plant - animal, dynamics of water and nutrients from soil, changes in botanical composition, and seasonal variations in the stocking rate, grazing intensity and frequency. Models representing the growth of pastures in temperate regions have a timescale that prevent visualize changes generated in the long term, including the impact of changes in climate and grazing management. The assessment made in eleven years, allowed defining the long-term changes in climatic conditions throughout the year determined the growth model, providing a temporal dimension, which generates group of months, where November, December and January include with higher average growth rate and June, July and August with growth rates below $10 \mathrm{~K} \mathrm{DM} /$ ha/day (Figure1). 

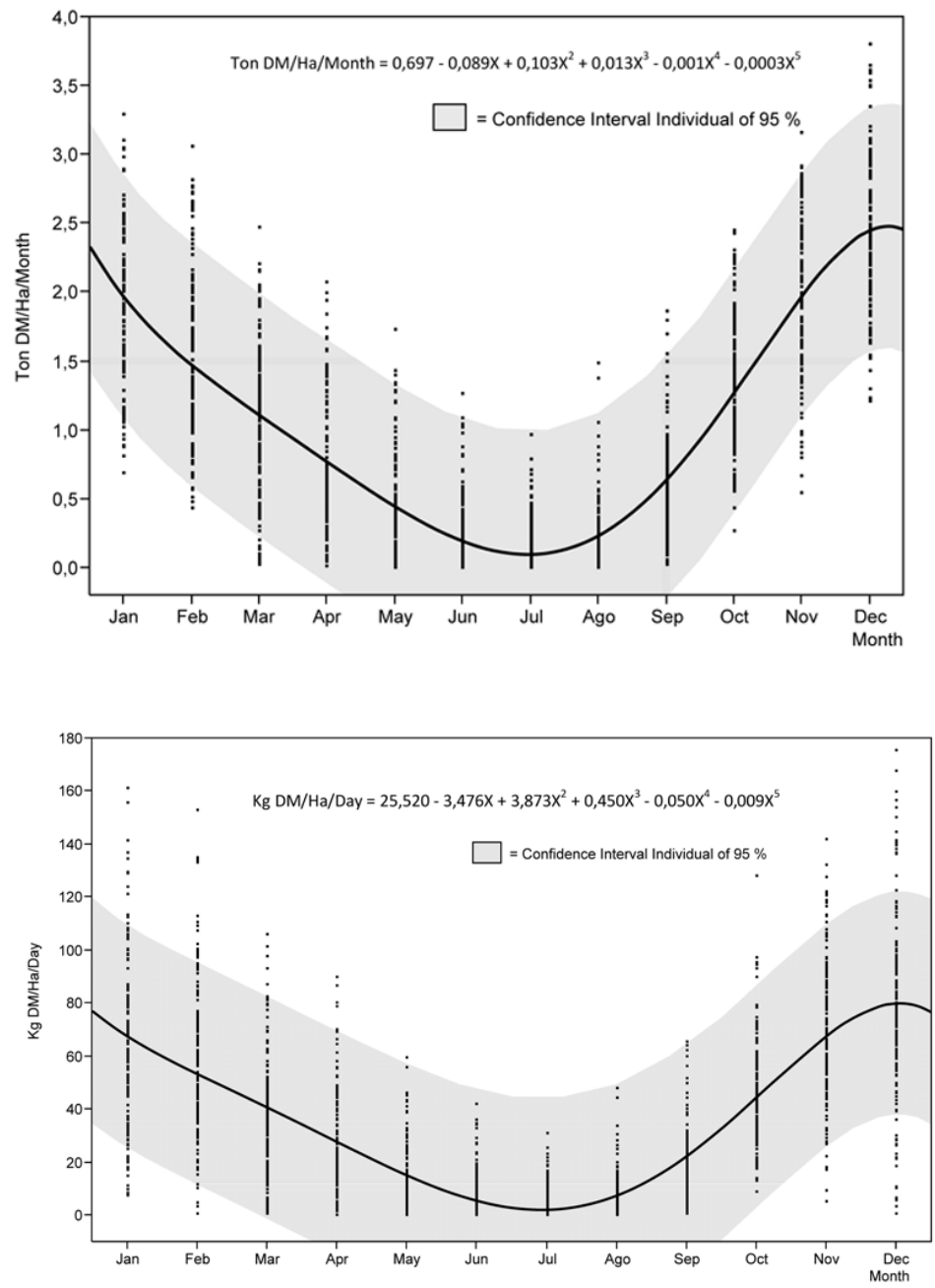

Figure 1. Polynomial fit and confidence interval $95 \%$ of the monthly dry matter yield (A), and pasture growth rate (B) in the target temperate area of Chile $(2002-2012)$.

\subsection{Seasonal distribution}

The growth model showed the concentration of dry matter, $50.3 \%$ annual yield occurred in spring-summer, $27.6 \%, 17.6 \%$, in autumn and only $4.5 \%$ in winter. These results were generated by the high growth rate presented pasture in the months of November and
December that was greater than $95 \mathrm{~kg} \mathrm{DM} / \mathrm{ha} /$ day. Humidity, temperature and radiation determining growth of pastures (Mc Calla, 2003) and, in temperate zones, the best relationship between these factors are generated in the period of spring (Skinner et al.,2009), as found in this research when the highest production was obtained in spring (Figure 2). 


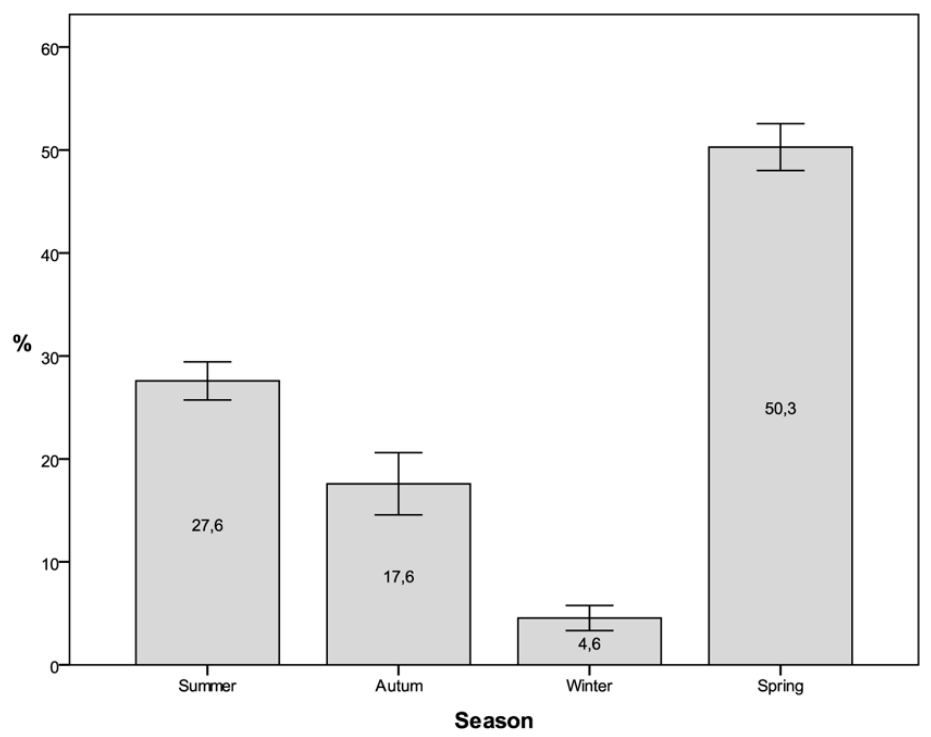

Figure 2. Seasonal distribution of dry matter production (\%) in the target temperate area of Chile (2002 - 2012).

\subsection{Annual production}

The annual dry matter production showed a variation from 9.80 Ton DM/ha to 17 Ton DM/ha with an average of 13.5 Ton DM/ha (Figure 3). The annual yield was grouped according to BLUP, which provided three categories, high, medium and low, giving each level the probability of occurrence over time. According to these results there is $18 \%$ of chance that pastures of this area have a high production level, this is, higher than 15.9 Ton $\mathrm{DM} /$ ha. The, probability of occurrence of such a medium value, which means achieving an average production of 13.49 Ton $\mathrm{DM} / \mathrm{ha}$, is $64 \%$. The possibility of having years with a low yield, which means to reach a pasture production 10.55 Ton DM/ha, was 18\% (Table 4).

In the temperate zone of Chile, there is no information on the probability of occurrence of different production levels over time, there are only results that show a high variability of yields in permanent pastures: 6 Ton DM/ ha to 12 Ton DM/ha, depending on latitude, climate, soil fertility management, plant nutrition and use systems: cutting or grazing. The values obtained in this study are located in the range of performance that show other temperate areas of the world (Stewart et al., 2014), but are low expectations in countries possessing livestock grazing, as New Zealand, which aims to achieve a level of performance above 22 Ton DM/ha.

The annual production variations are the result of various factors influencing the performance of a pasture being the most important the variations in humidity and temperature, over grazing and insect attack (Bell at al., 2001). Since this occurred in a period of 11 years gives strength to the results of this research considering that they were achieved during several years, with different levels of dry matter production, and having a remarkable level of probability of occurrence. 
Table 4. Cluster of years by level of dry matter production according to BLUP ranking.

\begin{tabular}{lccccc}
\hline Production level & No. Years & \multicolumn{3}{c}{ Ton DM/Ha/Day } & Significance BLUP \\
\hline & & average & maximum & minimum \\
\hline High & 2 & 16.45 & 17.00 & 15.90 & $\mathrm{P} \leq 0.05$ \\
\hline Medium & 7 & 13.49 & 14.20 & 12.20 & $\mathrm{P}>0.05$ \\
\hline Low & 2 & 10.55 & 11.30 & 9.80 & $\mathrm{P} \leq 0.05$ \\
\hline Total & 11 & & & \\
\hline
\end{tabular}

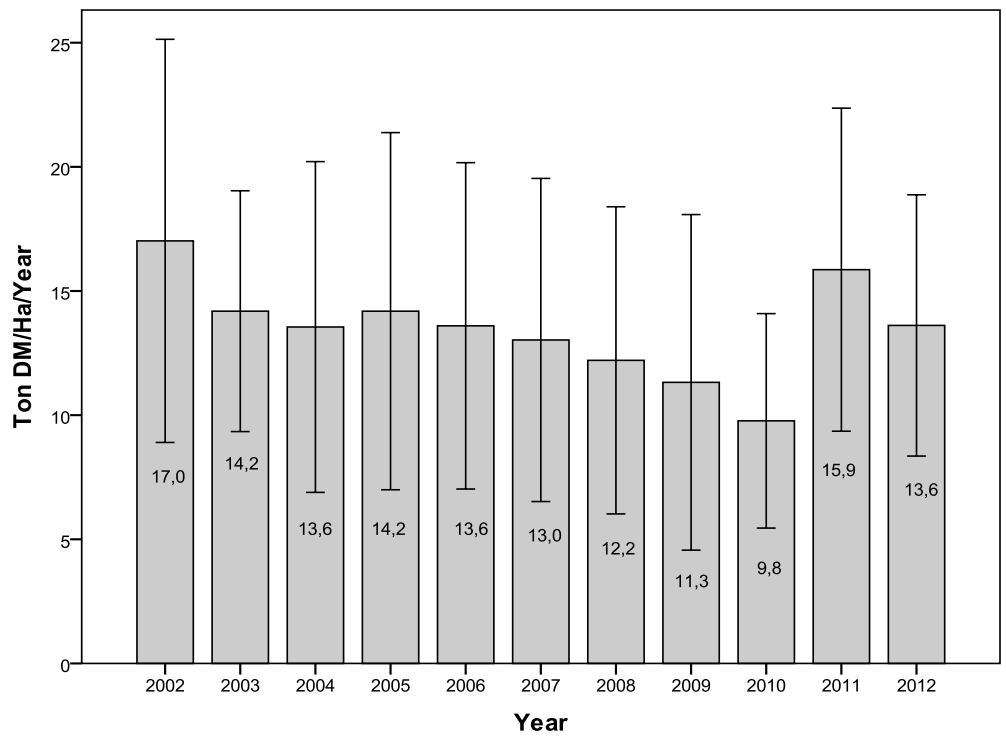

Figure 3. Annual dry matter production (Ton DM/ha) in the target temperate area of Chile $(2002-2012)$.

\subsection{Forage quality}

Plant quality is predominantly controlled by genetic and physiological factors. However, external factors such as climate and soil fertility, pest pressure, cultivation, fertilization, utilization and conservation methods, can significantly change the quality of plant (Wang et al., 2008; Martínez-Ballesta et al., 2010).

The nutritional value of pastures is determined by the species composition of the pastures and plant growth stage at the time of use. Changes in forage quality are determined by several factors, including the increasing maturity, season, soil nutrient content, frequency and intensity of grazing and utilization system. This investigation determined dry matter, protein, neutral detergent fiber, acid detergent fiber and metabolic energy throughout the year.

Dry matter content: This value is not an indicator of quality but its determination allows linking all quality attributes, which are measured on the basis of dry matter forage. The analysis of variance mixed model, determined by the components of variance, indicated 
that $75 \%$ of the total variation in the percentage of dry matter forage is attributed to seasonality. The year and the different types of pastures did not generate significant differences $(p>0.05)$.

The results were fitted to a polynomial curve fifth grade (Figure 4), with a significance level ( $p \leq 0.0001$ ), while months were grouped according to the ranking
BLUP at three levels (Table 5). Two summer months, like January and February, had the highest dry matter content which averaged $22.34 \%$. On a medium level were located the months of July, August, September, December, March and May, averaging 18.2\%. The months of lower dry matter content were October, November, April and June.

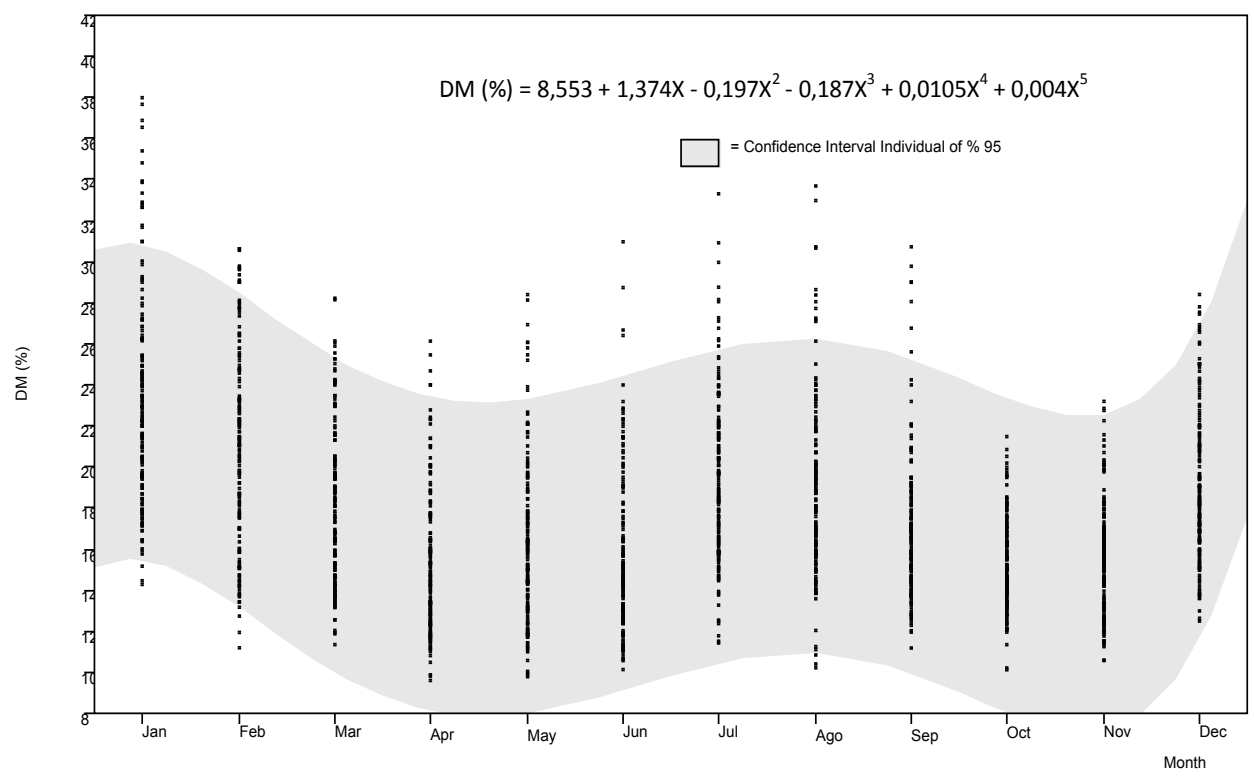

Figure 4. Polynomial fit and confidence interval $95 \%$ of the dry matter content (\%) in the target temperate area of Chile (2002 - 2012).

Table 5. Month clustering of the percentage of dry matter forage according to BLUP ranking

\begin{tabular}{|c|c|c|c|c|c|}
\hline Dry matter level & No. Months & & $\% \mathrm{DM}$ & & Significance BLUP \\
\hline & & average & maximum & minimum & \\
\hline High & 2 & 22.34 & 23.22 & 21.46 & $\mathrm{P} \leq 0.05$ \\
\hline Medium & 6 & 18.12 & 19.39 & 16.20 & $\mathrm{P}>0.05$ \\
\hline Low & 4 & 15.43 & 15.64 & 15.24 & $\mathrm{P} \leq 0.05$ \\
\hline Total & 12 & & & & \\
\hline
\end{tabular}

Variations in dry matter content were determined by the season and the progress in the growth stage of the plants. In summer a significant proportion of plants grasses, the main component of the botanical composition, were affected by their tillers spiky factor that determines the lower water content. In early spring periods, dry matter levels decrease, since the plants are in vegetative state and actively growing. These seasonal variations generate significant differences 
in consumption of animals, resulting from changes in digestibility and palatability of forage.

In the winter period it is common that plants have low dry matter content, because they are in a vegetative state, but in the months of July and August, the percentage of dry matter of the pasture was found here to be higher than $19 \%$ intermediate value in the range of dry matter pasture grazing. The highest percentage of dry matter was recorded in these two months, and can be related to diversity and genetic variability of species in pastures and reduced cold tolerance that have experienced some cultivars of Lolium perenne L. species, principal component of pastures (Hulke et al., 2008). In a scenario of changing in the climate conditions, where plants grasses are subjected to higher temperatures during the growing season, species and cultivars reduce their ability to withstand cold conditions, which generate in stress but induce an increased cold resistance by increasing the cell walls, and thereby, the dry matter production (Thorsen and Höglind, 2010).
Protein content: The analysis of variance mixed model, determined by the components of variance, indicated that $95 \%$ of the total protein content area variation in forage is attributed to seasonality. The year and the different types of pastures did not generate significant differences $(p>0.05)$.

The protein content of pastures throughout the year produced a polynomial curve fifth grade (Figure $5)$ with a level of significance ( $p \leq 0.0001)$, while months were grouped according to the ranking BLPU in three categories (Table 6). The months of August and September showed higher protein levels throughout the year, with an average of $26.81 \%$. In autumn, winter and spring portions corresponding to the months of March, April, May, June, July, October and November, the values were placed in a medium level with an average $22.64 \%$, and late spring and early summer (January, February and March) showed the lowest percentages averaging $16.92 \%$.

Table 6: Month clustering according to of percentage of Protein in the forage according to BLUP ranking

\begin{tabular}{|c|c|c|c|c|c|}
\hline Protein level & No. Months & & $\%$ Protein & & Significance BLUP \\
\hline & & average & maximum & minimum & \\
\hline High & 2 & 26.81 & 36.75 & 24.70 & $\mathrm{P} \leq 0.05$ \\
\hline Medium & 7 & 22.64 & 23.48 & 18.30 & $\mathrm{P}>0.05$ \\
\hline Low & 3 & 16.92 & 17.10 & 13.40 & $\mathrm{P} \leq 0.05$ \\
\hline Total & 12 & & & & \\
\hline
\end{tabular}

These results showed that pastures exhibited a high nutritional value throughout the year, because the average content area fluctuated between $16.15 \%$ and $27.90 \%$, all higher than those reported by Anrique (2014) for temperate pastures of Chile. The differences between this study and measurements made in other areas of the temperate zone are related to the frequency and intensity of use of the pasture because in the our study area, grazing management was based on an infrequent and intense use, which allowed the animals consume adequate level of forage dry matter with high content of protein. This type of use aims to achieve greater efficiency in the use of the pasture, in contrast to the individual production of the animals, but allows a greater production per hectare (Peyraud and Delagarde, 2013) these results were maintained in all the years during this research. 
Protein levels are presented related plant nitrogen content available soil fertilization and generated from organic matter mineralization, absorption capacity of plants, temperature and humidity, in addition to the frequency and intensity of grazing (Mora et al., 2007; Nuñez et al, 2007, Marschner, 2012). All these factors relate to the season and specifically, with the month. The results showed that in the period of increased mineralization, coinciding with the application of nitrogen fertilizer, high protein levels in plants were observed, specifically in the autumn and early spring, period in which plants have been growing low level of dry matter and fiber. Protein levels are presented related to plant nitrogen content (available from soil fertilization and generated from organic matter mineralization), absorption capacity of plants, temperature and humidity, in addition to the frequency and intensity of grazing (Mora et al., 2007; Nuñez, et al., 2007, Marschner, 2012). All these factors relate to season, and specifically, with the months of the year. The results showed that in the period of increased mineralization coincides with the application of nitrogen fertilizer. High protein levels were observed in plants, specifically in the autumn and early spring period, when the plants have vegetative state with low level of dry matter and fiber, which transforms the forage in a high nutritional feed and a good digestibility value.

Nitrogen nutrition is largely considered as the main factor affecting protein concentration in plants. In general, the concentration of crude protein continues to increase with $\mathrm{N}$ applied in amounts beyond those needed to obtain the maximum growth (Marschner, 2012). This is the reason why in this research high protein values were achieved in pastures receiving considerable levels of nitrogen fertilization (average $120 \mathrm{~kg} \mathrm{~N} /$ ha), with a high rate of organic matter mineralization. The lowest values were recorded in the months of December, January and February, due to advances in the state of maturity of the plants, because the climatic conditions of that period, the increased temperature and radiation induces the plant to generate floral stems and spikes, increasing fiber levels and reducing the cell and thus the protein content level.

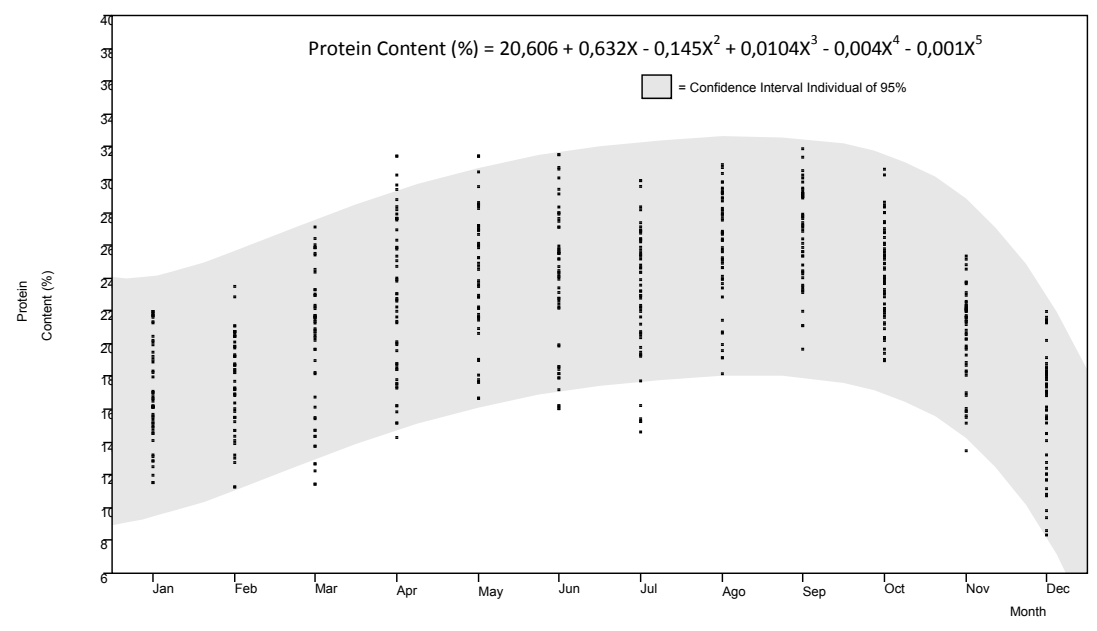

Figure 5. Polynomial fit and confidence interval 95\% of the protein content in the target temperate area of Chile (2002 - 2012). 
Fiber content: The analysis of variance mixed model, determined by the components of variance, indicated that $82 \%$ of the total variation in the percentage of $\mathrm{ADF}$ and $88 \%$ of the total variation of the NDF is attributed to seasonality. The year and the different sites of pastures did not generate significant differences $(p>0.05)$. The results from fiber content indicate the importance that this parameter has for pastures affected by changes in climate, humidity, temperature and nutrient availability in the soil. The results of ADF and NDF were modeled in a polynomial curve fifth grade (Figures 6 and 7) with a level of significance ( $p \leq 0.0001)$, while months were grouped according to the ranking BLUP into three categories: high, medium and low (Tables 7 and 8). Plant fibers include cellulose, hemicellulose, pectin, lignin and phenolic acids. These compounds vary in the level and speed that are degraded, lignin being the only compound that is entirely indigestible in the digestive tract of ruminants. The NDF constituted by total cell wall cellulose, hemicellulose and lignin, is an important value in the feeding of grazing animals, since it determines the level of intake. Increases in the values of NDF indicated a reduction in intake and consequently a reduction of animal production (Holmes et al., 2002). The values fibers in pastures of the temperate area of Chile are between 34\% and 55\% (Anrique, 2014).

Fiber levels obtained in this research relate to the content portion of pasture dry matter and consequently the maturity stage of the plants, a process that is determined by the grazing system and the season. The highest levels of NDF were obtained during the months of January, February, March, April, November, December and June, with an average of $56.71 \%$ NDF, when the plants are in advanced stages of maturity or are subject process temperature stress. A medium level $(53.08 \% \mathrm{NDF})$ was produced during the months of May, July, August and October, when the plants are in a vegetative state. Significantly different from the rest of the month was September with $48.6 \%$ of NDF period in which plants are initiating the explosive growth of spring. The values obtained are situated in the upper range reported by Anrique (2014).

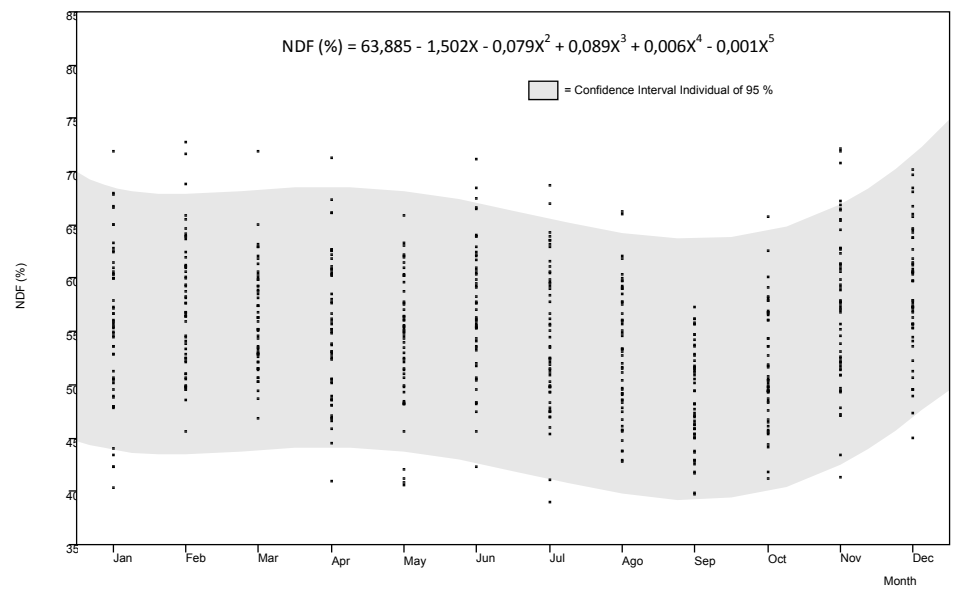

Figure 6. Polynomial fit and confidence interval 95\% of the content of NDF (\%) in the target temperate area of Chile (2002 - 2012). 
Table 7. Month clustering according to of percentage of NDF in the forage according to BLUP ranking.

\begin{tabular}{lccccc}
\hline Level & No. Months & \multicolumn{3}{c}{ \% NDF } & Significance BLUP \\
\hline & 7 & average & maximum & minimum & \\
\hline High & 7 & 56.71 & 58.44 & 55.30 & $\mathrm{P} \leq 0.05$ \\
\hline Medium & 4 & 53.08 & 53.94 & 51.22 & $\mathrm{P}>0.05$ \\
\hline Low & 1 & 48.62 & 48.62 & 48.62 & $\mathrm{P} \leq 0.05$ \\
\hline Total & 12 & & & & \\
\hline
\end{tabular}

The ADF fiber fraction, consisting of cellulose and lignin, as previously indicated, is related to forage digestibility and the capacity to produce animal milk and meat (Holmes et al., 2002). The value of ADF in the temperate pasture ranges in between $22 \%$ and $40 \%$, as reported by Anrique (2014). The high levels were found in th present study during the months from November, December,
January and February, corresponding to a part of spring and summer. The largest proportion of the months were in the medium level with an average of $28.25 \% \mathrm{ADF}$, is March, April, May, June, July, August. With the lower value of ADF September was achieved with $25.39 \%$ ADF. All results were in an intermediate range, according to the information reported by Anrique (2014).

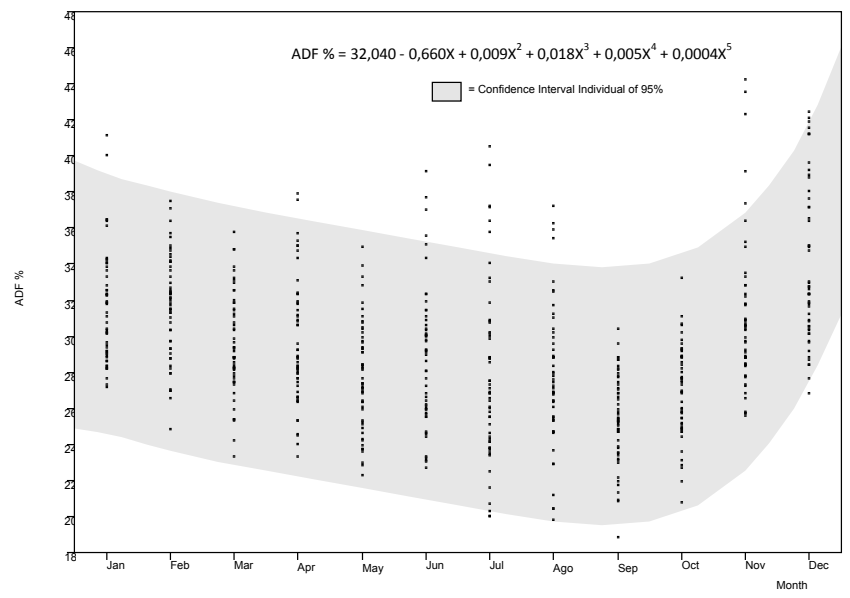

Figure 7: Polynomial fit and confidence interval 95\% of the content of ADF (\%) in pastures grown in the target temperate area of Chile (2002 - 2012).

Table 8: Month clustering of the percentage of ADF in the forage according to BLUP ranking.

\begin{tabular}{lccccc}
\hline Level & No. Months & \multicolumn{3}{c}{ \% ADF } & Significance BLUP \\
\hline High & & average & maximum & minimum & \\
\hline Medium & 4 & 32.18 & 34.07 & 30.84 & $\mathrm{P} \leq 0.05$ \\
\hline Low & 7 & 28.25 & 29.58 & 27.14 & $\mathrm{P}>0.05$ \\
\hline Total & 1 & 25.39 & 25.39 & 25.39 & $\mathrm{P} \leq 0.05$ \\
\hline
\end{tabular}


Variations in fiber content of temperate pasture area in Chile indicated that the forage supply not only conditions differences in production between seasons, but also quality, which determines the need to maintain a permanent adjustment the quantities and qualities offered to animals throughout the year.

The general trend indicated that pastures maintained through the years the changes that occur in the levels of fiber (ADF and NFD), as affected by season. This means that in addition to adjusting the stoking rate adjustment is needed also in diets, since variations in quality and quantity remain constant over the years.

\section{Conclusions}

The annual dry matter production in permanent pastures showed a variation from 9.80 Ton DM / ha / year to 17 Ton DM/ha/year, with an average of $13.5 \mathrm{Ton} \mathrm{DM} / \mathrm{ha} / \mathrm{year}$, where the probability of occurrence of a year with high production (16.45 Ton $\mathrm{DM} /$ ha / year) was $18 \%, 64 \%$ medium production (13.49 Ton $\mathrm{DM} /$ ha/year), and low production $18 \%$ (10.55 Ton DM/ha/year). The seasonal distribution of production, concentrated its performance in spring, and the highest performing months were November, December, January, with average growth per day $72 \mathrm{~kg} \mathrm{DM} / \mathrm{ha}$. The months of January and February showed the highest percentages of dry matter $(22.34 \%)$. The quality measured as protein and fiber, does not present statistical differences between years. Statistically significant differences were found only in the case of the effect of seasonality. The months where pastures have the highest protein content were August and September, while the lowest NDF concentration, significantly different from the rest, it was September with a $48.6 \%$, while the ADF concentration reached a $25.39 \%$. In production of significant differences between years were presented.
The seasonal distribution showed a concentration in spring. Variations in dry matter content and quality based on protein, NDF and ADF generated only seasonal differences. The general trend indicated that pastures maintained throughout the years seasonal changes. This means that, in addition to adjusting the stoking rate, adjustment is also needed for diets, since variations in pasture quality and quantity remain constant over the years.

\section{References}

Agouridis, T.C., Workman, R.S., Warner, C.R., Jennings, D.G. 2005 Livestock grazing management impacts on stream water quality: A review. Journal of the American Water Resources Association. 41, 3, $591-606$.

Andrews, M., Scholefield, D., Abberton, M.T., McKenzie, B.A., Hodge, S., Raven, J.A. 2007. Use of white clover as an alternative to nitrogen fertiliser for dairy pastures in nitrate vulnerable zones in the UK: productivity, environmental impact and economic considerations. Annals of Applied Biology. 151: 11-23.

Adams, C., Frantz, J., Bugbee, B. 2013. Macroand micronutrient-release characteristics of three polymer-coated fertilizers: Theory and measurements. Journal Plant Nutrition Soil Science. 176, 76-88

Anrique, G.R. 2014. Composición de alimentos para el ganado bovino. Universidad Austral de Chile, Consorcio Lechero, INÍA Ministerio de Agricultura. Imprenta América, Valdivia, Chile.

Beecher, M., Hennessy, D., Boland, T.M., McEvoy, M., O’Donovan, M. Lewis. E. 2013. The variation in morphology of perennial ryegrass cultivars throughout the grazing season and effects on organic matter digestibility. Grass and Forage Science. 70(1) p.19-29. 
Bell, N.L., Townsend, R.J., Popay, A.J., Mercer, C.F., Jackson, T.A. 2011. Black beetle: lessons from the past and options for the future. Pasture Persistence Symposium. Grassland Research and Practice Series. 15, 119-124.

Cameron, K.C., Di, H.J., Moir J.L. 2013. Nitrogen losses from the soil/plant system: a review. Annals of Applied Biology. 162, 145-173.

Cartes, P., Jara, A., Demanet, R., Mora, M.L. 2009. Urease activity and nitrogen mineralization kinetics as affected by temperature and urea input rate in southern Chilean Andisols. Journal Soil Science Plant Nutrition. 9 (1): 69-82

Corson, M.S., Rotz, C.A., Skinner, R.H., Sanderson, M.A. 2007. Adaptation and evaluation of the Integrated Farm System Model to simulate temperate multiple-species pastures. Agricultural Systems. 94, 502-508.

Delagarde, R., O'Donovan, M. 2005. Modelling of herbage intake and milk production by grazing dairy cows. In: Murphy, J.J. (ed.). Utilisation of grazed grass in temperate animal systems. Proceeding of a sateliteworshop of the XXth International Grassland Congress, July, 2005. Cook, Ireland. Wageningen Academic Publishers. Wageningen, Netherland. p: 89-104.

Fricke, T., Wachendorf, M., 2013. Combining ultrasonic sward height and spectral signatures to assess the biomass of legume-grass swards. Computers and Electronics in Agriculture. 99, 236-247

Giller, KE., Chalk P., Dobermann, A., Hammond, L., Heffer, P., Ladha, J.K., Nyamudeza, P., Maene, L., Ssali, H., Freney, J. 2004. Emerging technologies to increase the efficiency of use of fertilizer nitrogen. In: Mosier AR, Syers JK, Freney JR, (eds). Agriculture and the nitrogen cycle: assessing the impacts of fertilizer use on food production and the environment. Washington, DC: Island Press. p. 35-51.
Holmes, C.W., Brookes, I.M., Garrick, D.J., Mackenzie, D.D.S., Parkinson, T.J., Wilson, G.F., 2002. Milk production from pasture: Principles and practice. Palmerton North, New Zealand Massey University Press. 480 p.

Hulke, B.S., Watkins, E., Wyse, D.L., Ehlke, N.J. 2008. Freezing tolerance of selected perennial ryegrass (Lolium perenne L.) accessions and its association with field winterhardiness traits. Euphytica. 163, 131-141.

Kennedy, E., O’Donovan, M., Murphy, J.P., O’Mara, F.P., Delaby, L. 2006. The effect of initial spring grazing date and subsequent stoking rate on the grazing management, grass dry matter intake and milk production of dairy cows in summer. Grass and Forage Science. 61(4): 375 -384.

Li, F.Y., V.O, Snow., V.O., Holzworth, D.P. 2011. Modelling the seasonal and geographical pattern of pasture production in New Zealand. New Zealand Journal of Agricultural Research. 54(4): 331 -352 .

Marschner, P. 2012. Marschner's Mineral Nutrition of Higher Plants. Third Edition Academic Press, Elsevier. San Diego, USA. 482 p.

Martínez-Ballesta, M.C., Dominguez-Perles, R., Moreno, D.A., Muries, B., Alcaraz-López, C., Bastías, E., García-Viguera, C., Carvajal, M. 2010. Minerals in plant food: effect of agricultural practices and role in human health: A review. Agron. Sustain. Dev. 30, 295-309.

Mc Calla, D.G., Bishop-Hurley, G.J. 2003. A pasture growth model for use in a whole-farm dairy production model. Agricultural Systems. 76, $1183-1205$.

Mora, M.L., Cartes, P., Núñez, P., Salazar, M., Demanet, R. 2007. Movement of $\mathrm{NO}_{3}--\mathrm{N}$ and $\mathrm{NH}_{4}+-\mathrm{N}$ in an Andisol and its influence on ryegrass production in a short term study. Journal of Soil Science and Plant Nutrition. 7, 46-63. 
Núñez, P., Demanet, R., Matus, F., Mora, G.M. 2007. Grazing management, ammonia and nitrous oxide emissions: A general view. Journal of Soil Science and Plant Nutrition. 7(3): 61-99.

Owens, D., McGee, M., Boland, T. 2008. Intake, rumen fermentation, degradability and digestion kinetics in beef cattle offered autumn grass herbage differing in regrowth interval. Grass and Forage Science. 63, 369-379.

Pembletona, K.G., Rawnsleya, R.P., Burkittb, L.L. 2012. Environmental influences on optimum nitrogen fertiliser rates for temperate dairy pastures. European Journal of Agronomy. 45, $132-141$.

Peyraud, J.L., Delagarde., R. 2013. Managing variations in dairy cow nutrient supply under grazing. Animal. 7(Suppl. s1):57-67.

Sadzawka, R.A., Carrasco, R.M.A., Grez, Z.R., Mora, G.M., Flores P.H., Neaman, A. 2006. Métodos de análisis recomendados para los suelos de Chile. Revisión 2006. Centro Regional de Investigación La Platina INIA. Serie Actas INIA N 34. Santiago, Chile. 164 p.

Skinner, R.H., Corson M.S., Rotz, C.A. 2009. Comparison of two pasture growth models of differing complexity. Agricultural Systems. 99, 35-43.

Soto, P., Teuber, N. 1982. Evaluación de la disponibilidad de forraje bajo pastoreo. En: Soto, P. (ed.) Seminario de metodología de evaluación de praderas. Instituto de Investigaciones Agropecuarias, Santiago, Chile. pp: 132-147.

Stewart, A., Hayes, R. 2011. Ryegrass breeding - balancing trait priorities. Irish Journal of Agricultural and Food Research. 50, 31-46.
Stewart, A., Kerr, G., Lissaman, W., Rowarth, J. 2014. Pasture and forage plants for New Zealand. Grassland Research and Practice Series $N^{\circ} 8$. New Zealand Grassland Association. Taieri, Fairfield, Dunedin, New Zeland. 139 p.

Teuber, K.T. 2009. Praderas permanentes en las zonas lecheras de Chile. Curvas de crecimiento, distribución y producción. Consorcio Lechero, Inia. Osorno, Chile. 62p.

Thorsen, S.M., Höglind, M. 2010. Assessing winter survival of forage grasses in Norway under future climate scenarios by simulating potential frost tolerance in combination with simple agroclimatic indices. Agric. Forest Meteorol. 150, 1272-1282.

Van Soest, P.J. 1994. Nutritional Ecology of the Ruminant. Second Edition. Comstock Publishing Associates. Ithaca, United States. 488 p.

Varmuza, K., Filzmoser, P. 2009. Introduction to multivariate statistical analysis in chemometrics. CRC Press, London England. 336 p.

Vico, G., Porporato, A. 2008. Modeling C3 and C4 photosynthesis under waterstressed conditions. Plant Soil. doi:10.1007/s11104-008-9691-4.

Wang, L., Schjoerring, J.K. 2012. Seasonal variation in nitrogen pools and $15 \mathrm{~N} / 13 \mathrm{C}$ natural abundances in different tissues of grassland plants. Biogeosciences. 9, 1583-1595.

Wang, Z.-H., Li, S.-X., Malhi, S. 2008. Effects of fertilization and other agronomic measures on nutritional quality of crops. J. Sci Food Agric. 88, 7-23.

Zaman, M., Saggar, S., Blennerhassett, J.D., Singh, J. 2009. Effect of urease and nitrification inhibitors on $\mathrm{N}$ transformation, gaseous emissions of ammonia and nitrous oxide, pasture yield and $\mathrm{N}$ uptake in grazed pasture system. Soil Biology and Biochemistry. 41, 1270-1280. 